minimum and a very strong but asymmetrical hydrogen bond. Although hydrogen bonds between nitrogen atoms are normally rather weak, these acids seem to provide a favourable opportunity for strong hydrogen bonding. Symmetrical-type hydrogen bonding would result in reasonable structures for both compounds, that is, infinite chains for aurocyanic acid, and a three-dimensional lattice based on linked octahedra for cobalticyanic acid. Further work is in hand and it may be noted that preliminary infra-red data on a number of related anhydrous acids indicate that they fall into two classes which resemble ferrocyanic acid or cobalticyanic and aurocyanic acids, respectively.

Measurements were made using nujol and fluorolube mulls, a Perkin-Elmer model 21 spectrometer with calcium fluoride, sodium chloride and potassium bromide prisms, and Infracord and Unicam $S P 200$ spectrometers.

The acids were prepared by standard procedures ${ }^{1-3}$ and dried in vacuo at $80^{\circ}-100^{\circ} \mathrm{C}$. The deutero acids were obtained either directly, using deuterium chloride and deuterium oxide, or by repeated exchange with deuterium oxide, and the extent of deuteration ( $>90$ per cent) was checked from examination of their proton resonance spectra in deuterium oxide solution.

We thank Mr. P. Nicholson for samples of $\mathrm{H}_{4} \mathrm{Fe}(\mathrm{CN})_{6}$ and the Ethyl Corporation of America for financial support to one of us (D. J.).

$$
\begin{aligned}
& \text { D. Jones } \\
& \text { D. F. Evans }
\end{aligned}
$$

Inorganic Chemistry Research Laboratories,

Imperial College of Science and Technology, London, S.W.7.

${ }^{1}$ Penneman, R. A., Staritzky, E., and Jones, L. H., J. Amer. Chern. Soc. 78, 62 (1956).

2 Hartley, E. A. J., J. Chem. Soc., 521 (1914)

${ }^{3}$ Heldt, Z., J. Org. Chem., 26, 3226 (1961).

- Albert, N., and Badger, R. M., J. Chem. Phys., 29, 1193 (1958).

- Speakman, J. C., and Mills, H. H., J. Chem. Soc., 1194 (1961).

- Hadzi, D., J. Chem. Soc., 5128 (1961), and references therein.

\section{Far-infra-red Absorption Spectra of some Complex Halides of Molybdenum and Tungsten}

IN a previous publication ${ }^{1}$ Adams and Gebbie reported the far-infra-red absorption spectra of some transition metal complex halides containing regular octahedral ions of the type $M X_{6}{ }^{n-}, X=$ halogen. We have now extended our observations to a series of halides of molybdenum and tungsten recently prepared by Edwards, Kennedy, Peacock and Said ${ }^{2}$.

The spectra were obtained by means of a far-infra-red interferometer, the samples being in the form of 'Nujol' mulls sealed in polythene cells; details of techniques and procedure have already been published ${ }^{1}$. The results are given in Table 1.

Table 1. FAR-INFRA-RED ABSORPTION FREQUENCIES $\left(\mathrm{CM}^{-1}\right)$ OF SOME COMPLEX HATIDES OF MO1v AND Wiv

$\begin{array}{lccc} & \nu_{3} & v_{4} & \text { Lattice mode (?) } \\ \mathrm{K}_{2} \mathrm{WCl}_{6} & 324 & 165 & 77 \\ \mathrm{R}_{2} \mathrm{WCl}_{6} & 306 & 160 & 66 \\ \mathrm{Cs}_{3} \mathrm{WCl}_{6} & 308 & 166 & 71 \\ \mathrm{~K}_{2} \mathrm{MoCl}_{6} & 340 & 174 & 74 \\ \mathrm{Rb}_{2} \mathrm{MoCl}_{6} & 334 & 172 & 70 \\ \mathrm{Cs}_{8} \mathrm{MoCl}_{6} & 325 & 170 & \\ \mathrm{~K}_{2} \mathrm{WBr}_{6} & 229 & 74 & - \\ \mathrm{Rb}_{3} \mathrm{WBr}_{6} & 220 & 78 & - \\ \mathrm{Cs}_{2} \mathrm{WBr}_{6} & 214 & 60 & \end{array}$

Spectra of the halides $M_{2}^{\prime}\left[\mathrm{MCl}_{6}\right], M=$ molybdenum or tungsten, are analogous to those found for compounds such as $\mathrm{K}_{2} \mathrm{PtCl}_{6}$ and $\mathrm{K}_{2} \mathrm{IrCl}_{6}$, a three-band spectrum being observed $^{1}$. The spectra of the molybdenum chlorides all had absorption near $230 \mathrm{~cm}^{-1}$; but as this increased if the sample was exposed to air, we consider it to be due to a breakdown product. Weak absorption was also found in
$\mathrm{Rb}_{2} \mathrm{WBr}_{6}$ and $\mathrm{Cs}_{2} \mathrm{WBr}_{6}$ at 116 and $114 \mathrm{~cm}^{-1}$ respectively. Absorption in the range $308-340 \mathrm{~cm}^{-1}$ is due to $v_{3}$ (metalchlorine stretching) and that at 160-174 to $v_{4}$ (metalchlorine bending). In the bromides, $M_{2} \mathrm{WBr}_{6}, \nu_{3}$ and $\nu_{4}$ are correspondingly lower and compare closely with those observed for $\mathrm{K}_{2} \mathrm{PtBr}_{6}$, namely, 240 and $78 \mathrm{~cm}^{-1}$. As expected $\nu_{3}$ is lower for the tungsten than for the molybdenum compounds, and it is interesting to note that $v_{4}$ follows this trend.

There is a marked dependence of $v_{3}$ (and to a lesser extent, $v_{4}$ ) on the nature of the cation. As the size of the cation is increased, cation-anion interactions decrease. The rise in $\gamma_{3}$ - and hence in the $M-X$ bond-strengthwith increasing ionic interaction may be caused, at least in part, by varying amounts of $d \pi-d \pi$ bonding between metal and halogen in the anion. This dative $\pi$-bonding, which Woodward and Ware ${ }^{3}$ have shown to be present in $\mathrm{PtCl}_{6}{ }^{2-}$ and $\mathrm{PtBr}_{6}{ }^{2-}$, will be favoured by the proximity of a relatively small cation such as $\mathrm{K}^{+}$.

In $\left(\mathrm{NEt}_{4}\right) \mathrm{WVCl}_{6}, v_{3}$ is at $329 \mathrm{~cm}^{-1}$ (ref. 4); in $\mathrm{Cs}_{2} \mathrm{WIVCl}_{8}$, $v_{3}$ is at $308 \mathrm{~cm}^{-1}$ and would presumably be a little lower in $\left(\mathrm{NEt}_{4}\right)_{2} \mathrm{WIVCl}_{6}$. Thus a drop of some $25 \mathrm{~cm}^{-1}$ in $v_{8}$ occurs as the oxidation state of tungsten is changed from +5 to +4 , comparable with that of $37 \mathrm{~cm}^{-1}$ for the +4 to +3 change in $\mathrm{K}_{2} \operatorname{IrCl}_{8}$ and $\mathrm{K}_{3} \operatorname{IrCl}_{6}$ (rof. 1 ).

The third, and lowest, frequency band found for the chlorides (Table 1) is in addition to the predicted infra-redactive internal modes of an isolated $\mathrm{MCl}_{6}{ }^{2-}$ ion. It was previously assigned to a lattice mode ${ }^{1}$, largely on the basis of the large shift it suffered $\left(45 \mathrm{~cm}^{-1}\right)$ in $M_{2}^{\prime} \operatorname{IrCl}_{6}$ when $M^{\prime}$ was changed from $\mathrm{K}^{+}$to $\left(\mathrm{NH}_{4}\right)^{+}$. An alternative assignment is to $v_{B}\left(f_{2} u\right)$, the inactive bending frequency, made active by the lower symmetry of the crystal lattice.

This work was in part carried out within the research programme of the National Physical Laboratory and is published by permission of the Director.

Department of Chemistry,

D. M. Adams University of Leicester.

H. A. GebBie

Basic Physics Division,

National Physical Laboratory, Teddington, Middlesex.

Department of Chemistry,

University of Birmingham, 15.

${ }^{1}$ Adams, D. M., and Gebbie, H. A., Spectrochim. Acta, 19, 925 (1963).

2 Edwards, A. J., Peacock, R. D., and Said, A., J. Chem. Soc., 4643 (1962); Kennedy, C., and Peacock, R. D., ibid. (in the press)
Kenned A.

3 Woodward, L. A., and Ware, M. J., Spectrochim. Acta, 19, 775 (1963).

${ }^{4}$ Adams, D. M., Chatt, J., Davidson, J. M., and Gerratt, J., J. Chem. Soc., $2189(1963)$.

\section{Polymorphism in Silicon Carbide}

SILICON carbide exists in two distinct crystalline polymorphs, the cubic or $\beta$-form, and the hexagonal or $\alpha$-form ${ }^{1-3}$. Although the crystal structure and related physical properties of the two forms of silicon carbide have been extensively investigated, the chemical relationship between the two silicon carbide polymorphs has apparently failed to receive equivalent attention. The problem was attacked by Baumann", who investigated both the chemistry of silicon carbide formation, and the rate of conversion of $\beta$-silicon carbide to $\alpha$-silicon carbide at several temperatures. Baumann observed that although $\beta$-silicon carbide began to transform to $\alpha$-silicon carbide slowly at $2,100^{\circ} \mathrm{C}$, the reaction was rapid at $2,300^{\circ} \mathrm{C}$.

The suggestion that the transformation from the cubic form to the hexagonal form may proceed via the vapour phase has been made by Slack ${ }^{5}$. Thus, if a solid-phase transition occurs at all, it must be very slow as compared with the vapour phase process. Indeed, Kistler ${ }^{6}$ summarized the problem when he stated, "It is probable, although $I$ believe the subject has not been sufficiently 